\title{
Analysis on Some Essential and Non-Essential Metals in Bulla of Enset (E. Ventricosum) with Supporting Soil sample in West Showa Zone
}

Teressa Bedada*, Alemayehu Abebaw

Department of Chemistry, Ambo University, P. O. Box 19, Ambo, Ethiopia

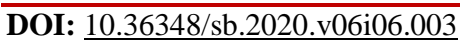

| Received: 17.03.2020 | Accepted: 24.03.2020 | Published: 30.06.2020

*Corresponding author: Teressa Bedada

\section{Abstract}

The aim of this study was to investigate the level of essential and non essential metals in Bulla of Ensete ventricosum and soil samples in West Showa Zone. $\mathrm{K}$ and $\mathrm{Na}$ were analyzed using FAES, Ca and Mg were determined complecometric titration method and the other metals with FAAS after appropriate quality control measures were undertaken to verify and maintain the quality of the data generated. The optimized wet digestion method for Bulla and soil analysis was found effective for all of the minerals and as it was evaluated through the recovery experiment, a good percentage recovery 96.85\% (Fe in Bulla) to $112 \%$ ( $\mathrm{Pb}$ in soil) was obtained for the minerals identified. The results of this study showed that the average concentrations were ranged in order decreasing in $\left(\mathrm{mgkg}^{-1}\right) 3366.28(\mathrm{~K})>1881.57(\mathrm{Na})>593.44(\mathrm{Mg})>$ $862.85(\mathrm{Ca})>55.68(\mathrm{Fe})>6.99(\mathrm{Zn})>3.09(\mathrm{Cu})>2.96(\mathrm{Mn}) . \mathrm{Cd}$ and $\mathrm{Pb}$ were not detected for Bulla and $3521.11(\mathrm{~K})>3497.85(\mathrm{Mg})>3461.59(\mathrm{Fe})>3294.93(\mathrm{Ca})>1096.89(\mathrm{Na})>(93.99(\mathrm{Mn})>16.74(\mathrm{Zn})>3.77(\mathrm{Cu})>0.26(\mathrm{Cd})$ for soil sample and $\mathrm{Pb}$ was not detected. The concentrations of the metals were also compared with recommended maximum permissible limits and some international reports; and found to be in a good agreement indicating no exposure risk of using the bulla and corm of Ensete ventricosumunder the current situation. Statistical test of significance using ANOVA revealed that there were significant differences $(\mathrm{P}<0.05)$ between the values of metals in the bulla and soil samples obtained from all the sampling sites except $\mathrm{Zn}$ and Fe for bulla and $\mathrm{Ca}$ in soil.

Keywords: Bulla of E. ventricosum, Essential and non -essential metals, Soil, wet digestion.

Copyright @ 2020: This is an open-access article distributed under the terms of the Creative Commons Attribution license which permits unrestricted use, distribution, and reproduction in any medium for non-commercial use (NonCommercial, or CC-BY-NC) provided the original author and source are credited.

\section{INTRODUCTION}

Ethiopia mainly depends on agriculture. Over 85 percent of its population lives in the rural area where crop production and animal husbandry is their main stay. Enset based farming systems play an important role in food security in Ethiopia [1]. Ensete ventricosumis one of the indigenous root crops widely cultivated in the Central, South and South Western parts of Ethiopia, but recurrent droughts have led to the expansion of Enset cultivation to other parts of the country $[2,3]$.

The genus Ensete comprises of 5-7 species, half of which are African, the other half Asian in origin. It is a perennial herbaceous root crop with long broad leaves and bulky pseudostem which grows wild in a number of countries in Central and Eastern Africa including Congo, Mozambique, Uganda, Tanzania and Zambia [3]. Ensete ventricosumcultivation in Ethiopia may have started around the $15^{\text {th }}$ century, south of Gibe
River. Wild Ensete ventricosum grows in the highland altitude range (1100-3100masl) of Ethiopia in small pockets around Bonga town and the Omo River valley. In contrast, cultivated Enset grows in a wider area comprising the Central, South and South-Western parts of Ethiopia, mainly at higher altitudes (1500-3100 masl) [4, 3]. Enset is gowns mainly in the South Nation Nationality Peoples Regional State followed by Oromia and Gambella Regional States [5, 6].

Ensete ventricosum parts contained high percent of water ( $85 \%$ to $90 \%)$, which is beneficial when used as fodder during dry periods. Ensete ventricosumcorm contained 17 of 20 amino acids. Leaves had $13 \%$ protein, among the highest available in Ethiopia, $20 \%$ crude fibre and $10 \%$ sugar. The pseudostem the main food source, was rich in $80 \%$ of soluble carbohydrates and $65 \%$ of starch, but has low protein content 4\% [7]. The Bulla of Enset has low in non-essential nutrients (lead and Cadmium) and rich in 
essential nutrients (calcium, magnesium, potassium, zinc and iron [8].

The main sources of heavy metals to plant are their growth media (soil, air, nutrient solution) from which these are taken up by the roots or foliage. So plants can easily be contaminated by heavy metals in the course of cultivation or later during the processing stage. The content of heavy metals is one of the criteria for the use of plant material as food or traditional medicines. Hence determination of mineral compositions in food and medicinal plant is essential for understanding their nutritive importance and health risk [9].

However, no literature report was found on comparative determination the concentration of essential and non-essential metals in Bulla of Ensete ventricosumwith its supporting soil samples. Therefore, the aim of this study to compare the level of essential and non-essential metals in Bulla of Ensete ventricosumand soil environment from different locations of West Showa Zone, Oromia Regional State, Ethiopia by using flame atomic absorption spectroscopy and flame emission atomic spectroscopy.

\section{MATERIALS AND METHODS \\ Instruments and Chemicals}

Polyethylene plastic bags, Electronic analytical balance with $0.0001 \mathrm{~g}$ sensitivity, A $250 \mathrm{ml}$ round bottomed flasks fitted and reflux condensers. Borosilicate volumetric flasks Measuring cylinders and micropipettes, Whatman filter paper (No.42 $150 \mathrm{~mm}$, England), Digestive furnace (Model KDN-20C, China), Flame Photometer (ELICO, CL-378, India) and flame atomic absorption spectrophotometer FAAS (Buck Scientific Model 210 VGG, USA). The reagents and chemicals used in this study were: $\mathrm{HNO}_{3}$ (65-68\%, UniChem ${ }^{\circledR}$ Chemical Reagent, India), $\mathrm{HClO}_{4}(70-72 \%$, Uni-Chem ${ }^{\circledR}$ Chemical Reagent, India), $\mathrm{H}_{2} \mathrm{O}_{2}(30 \%$, Uni- Chem $^{\circledR}$, India), Lanthanum chlorides hydrate (99.9\%, KIRAN LIGHI laboratories, India), EDTA-Na (98.5-101\%, Unic-Chem ${ }^{\circledR}$, India) and Stock standard of metals

\section{Description of the Study Areas}

The study areas were conducted in west Showa Zone, Oromia Regional State, Ethiopia. It was found between $8^{0} 17^{\prime}-9^{0} 56^{\prime} \mathrm{N}$ and $37^{0} 1^{\prime}-38^{0} 45^{\prime} \mathrm{E}$ and Altitude range 2000-3200 meters above sea level as indicated Table-1.

Table-1: Geographical location and Distance from Ambo and Addis Ababa of sampling sites

\begin{tabular}{|l|l|l|l|l|l|}
\hline Sample sites & $\begin{array}{l}\text { Distance from } \\
\text { Ambo(km) }\end{array}$ & $\begin{array}{l}\text { Distance from } \\
\text { Addis (km) }\end{array}$ & $\begin{array}{l}\text { Altitude range } \\
(\mathbf{m a s})\end{array}$ & $\begin{array}{l}\text { Latitude range } \\
(\mathbf{N})\end{array}$ & $\begin{array}{l}\text { Longitude } \\
\text { range(E) }\end{array}$ \\
\hline Dire Enchine & 40 & 154 & $2505-2634$ & $8^{\circ} 1-8^{\circ} 46^{\prime}$ & $37^{\circ} 35^{\prime}-37^{\circ} 38^{\prime}$ \\
\hline Jeldu & 72 & 120 & $2500-3200$ & $9^{\circ} 02^{\prime} 47^{\prime \prime}-9^{\circ} 15^{\prime}$ & $38^{\circ} 05^{\prime}-38^{\circ} 12^{\prime} 16^{\prime \prime}$ \\
\hline Jibat & 70 & 184 & $2000-3000$ & $8^{\circ} 35^{\prime}-8^{\circ} 50^{\prime}$ & $37^{\circ} 15^{\prime}-37^{\circ} 35^{\prime}$ \\
\hline
\end{tabular}

\section{Sample Collection and Protocol}

The Bulla of Ensete ventricosum samples were collected in January, 2016 from the three agricultural areas (woredas) with its supporting soil. Each sample was collected purposely from four different sub-sites (farm lands) to provide replicate samples. From the three agricultural areas Bulla can be prepared according to the traditional method. During harvest leaf and old leaf sheaths first removed from the edible designated plants, the edible designated plant out of the land were cut into three parts for the separation of pseudostem and Corm with knife. The leaf sheath was decorticated using a local made bamboo scraper while the leaf sheath was held on an incline at 45 to 80 degrees from the ground against a wooden plank. Then, the pseudostem was decorticated using bamboo scraper washed with distilled water and to get Bulla by squeezing pseudostem. The soil samples were collected from the surface $15 \mathrm{~cm}-25 \mathrm{~cm}$ [10] depth of the same four sampling areas of Enset by spade. Finally three Bulla and soil samples one from each stated areas were collected and put in clean cooled polyethylene plastic bags labeled and brought to the Ambo University laboratory.

\section{Sample Preparation}

Bulla and soil samples were collected from each sub-sites were air dried for $72 \mathrm{hr}$ to remove moisture and all clods and clumps. The four subsamples were mixed equal proportion together to form a composite sample that represents each sampling areas. The powdered two samples were placed in pre-cleaned screw capped polyethylene container and stored in desiccators containing calcium chloride to keep to constant dry weight till digestion [11].

\section{Optimization procedure for Bulla and Soil Samples}

The basic requirements for sample preparation for analysis are to get an optimum condition for digestion. To prepare a clear colorless bulla and soil sample solutions that were suitable for the analysis using FAAS and FAES a mixture of $\mathrm{NHO}_{3}$ and $\mathrm{HCO}_{4}$ were used for optimization of digestion procedure for Bulla sample where as $\mathrm{H}_{2} \mathrm{O}_{2}$ in the case of soil sample as it is a strong oxidizing agent. After the optimized condition was obtained the sample were digested by using wet digestion principles.

\section{Method Validation and Quality Control Method Validation Precision and Accuracy}

Precision and accuracy of the analytical method was assessed by repeatability and recovery studies of matrix spike (MS). Recovery study was performed by spiking three replicate of Bulla and soil 
samples with a known concentration of metal standard solution (mid-range calibration concentration). The spiked samples were then subjected to the same digestion procedure like the actual sample. Precision was expressed as relative standard deviation (RSD) of the three replicate results and calculated as:

$$
R S D \%=\frac{S}{\bar{X}} \times 100
$$

Where RSD is relative standard deviation, $\mathrm{S}$ is standard deviation and $\bar{X}$ is mean of measurements.

Accuracy is expressed as matrix spike recovery and the percent recovery results were calculated by the following equation [12].

$$
\% R=\frac{C_{\text {Spike sample_}} C_{\text {Unspike sample }}}{C_{\text {added }}}
$$

\section{Instrument Detection Limit (IDL)}

Instrument detection limits (IDLs) was estimated by taking seven replicate measurements of the calibration blank (Distilled water). The IDL is calculated to the concentration equal to three times the standard deviation of seven replicate measurements of blank [13].

$$
I D L=3 X S_{b}
$$

Where, $S_{b}$ is standard deviation of blank $(n=7)$ and IDL is Instrument detection limit

\section{Method Detection Limit (MDL)}

Method detection Limit is the minimum concentration of analyze that can be identified measured and reported with $99 \%$ confidence that the analyze concentration is greater than zero. MDL was based up on seven replicate measurements of a series of calibration blanks (reagent blank) that are carried through the entire sample preparation scheme [14]. The MDL was calculated by:

$$
M D L=S \times T-\text { test }
$$

Where, $\mathrm{S}$ is standard deviation of the replicated analysis with $\mathrm{n}-1$ degree of freedom, $\mathrm{t}=3.71$ ( $\mathrm{T}$ - test value for a $99 \%$ of confidence level for six degrees of freedom)

\section{Method Quantification Limit (MQL)}

Method quantification limit was obtained from analysis of seven reagents blanks which were digested in the same digestion procedure as actual samples. The method quantification limit was calculated by multiplying standard deviation of the reagent blank by ten plus the mean of the reagent blank signals [14].

$$
M Q L=\bar{X}_{\text {blank }}+10 \times \mathrm{S}_{\text {blank }}
$$

Where, $\bar{X}_{\text {blank }}$ is the mean of blank, $\mathrm{S}_{\text {blank }}$ is standard deviation of the blank.

\section{Contamination Control Method Blank}

The method blank accounts for contamination that may occur during sample preparation and analysis.
These could arise from the reagents, the glassware or the laboratory environment [11]. Sucrose was used as matrix since there was no other plant and clear soil that can serve as the matrix for the bulla and soil samples. The blank which was prepared from the sucrose and any reagents used for the digestion was taken through the entire measurement procedure to detect contamination from reagents, sample handling, and the entire measurement process [13].

\section{Laboratory Control Sample}

Laboratory Control Sample (LCS) is an aliquot of an environmental sample to which known qualities of the method analyses are added in the laboratory. The LCS would contain known concentrations of target analytes. In this study, sucrose spiked with the target analyte of known concentration the same to sample spike was carried through the same, entire sample preparation and analysis procedures used for samples. Triplicates of LCSs were analyzed along with each batch of the Bulla and soil samples. LCS recoveries for each metal of interest were calculated using $[14,15]$.

$$
\% R=\frac{\mathrm{C}_{\text {found }}}{\mathrm{C}_{\text {added }}} x 100 \text {, }
$$

Where $\% \mathrm{R}$ is percent recovery, $C_{\text {found }}$ is concentration of analyte found in the sample and $C_{\text {added }}$ Concentration of analyte added to the sample; which were used to control overall analytical method accuracy which is independent of sample matrix effects.

\section{Matrix Spike}

Matrix spike (MS) is portion of a sample spiked with known concentration(s) of target analyte(s). The spiking occurs prior to sample preparation and analysis. The purpose of a matrix spike sample is to determine whether the sample matrix contributes bias to the analytical results [16].

In this study, Matrix spike was prepared for each sample item by spiking aliquots of $0.5 \mathrm{~g}$ of each bulla, corm and soil samples with $2.5 \mathrm{ml}$ standards mixture solution giving concentrations of $1.0 \mathrm{mgL}^{-1}$ for $\mathrm{K}, \mathrm{Zn}, \mathrm{Cd}$ and $\mathrm{Pb} ; 2.0 \mathrm{mgL}^{-1}$ for $\mathrm{Na}, \mathrm{Cu}, \mathrm{Fe}$ and $\mathrm{Mn}$. They were all carried through the same digestion and analysis steps as an unspiked sample. And the mean recovery values of Matrix Spikes were calculated using equation.

$$
\% R=\frac{C_{\text {Spike sample }} C_{\text {Unspike sample }}}{C_{\text {added }}}
$$

\section{Transfer Factor of Metals from soil to Ensete ventricosum}

Transfer factor is the ratio of the concentration of metals in a plant to the concentration of metals in soil. Transfer factor for each metals was computed based on the method Harrison and Chirgawi [17] described by Uwash et al., [18] according to the following formula 


$$
T F=\frac{P_{M \mu g g^{-1}}}{S_{m} \mu g g^{-1}}
$$

Where, $\mathrm{p}_{\mathrm{m}}$ is metals concentration in plant and $\mathrm{S}_{\mathrm{m}}$ is metals concentration in soil

\section{Statistical Analysis}

Analysis of variance (ANOVA) and F-test at $\mathrm{p}<0.05$ are used to examine statically significant differences in the mean concentrations of metals among groups of soil and Bulla of E. Ventricosum. A probability level of $p<0.05$ is considered statistically significant. All statistical analysis was done by Microsoft Office Excel 2007 was used for data analysis and SPSS Version 16.0 Software Window was used for Analysis of variance (ANOVA) and correlation between metals in Bulla and soil samples [14].

\section{RESULTS AND DISCUSSION Optimization Digestion Procedures of Soil and Bulla Samples}

From the optimization procedure, digestion of $0.5 \mathrm{~g}$ of soil with a mixture of total volume $4.5 \mathrm{~mL}$ which, $2 \mathrm{ml}$ of concentration of $\mathrm{HNO}_{3}, 1.5 \mathrm{ml}$ concentration of $\mathrm{HClO}_{4}$ and $1 \mathrm{ml}$ concentration of $\mathrm{H}_{2} \mathrm{O}_{2}$ digested at a temperature of $230^{\circ} \mathrm{C}$ for $2: 30$ hours gave a clear colorless solution as indicated Table- 2 .

In the same manner, the optimum conditions for bulla sample digestion were a reagent mixture of total volume $3.5 \mathrm{~mL}$ which, $2 \mathrm{ml} \mathrm{HNO}_{3}$ and $1.5 \mathrm{ml}$ of $\mathrm{HClO}_{4}$ digested at a temperature of $210^{\circ} \mathrm{C}$ for $2 \mathrm{hr}$ gave a clear colorless solution as indicated Table-3.

\section{Digestion of Bulla and Soil Samples}

Applying the optimized procedureas indicated (Table 2 and 3) $0.5 \mathrm{~g}$ of air dried and homogenized Bulla and Soil samples were transferred into a $250 \mathrm{~mL}$ round bottomed flask. To this was added $3.5 \mathrm{ml}$ a mixture of $\mathrm{HNO}_{3}(69-72 \%)$ and $\mathrm{HClO}_{4}(70 \%)$ with a volume ratio of $2: 1.5$ for Bulla and $4.5 \mathrm{ml}$ a mixture of $\mathrm{HNO}_{3}(69-72 \%), \mathrm{HClO}_{4}(70 \%)$ and $\mathrm{H}_{2} \mathrm{O}(30 \%)$ with a volume ratio of $2: 1.5: 1$ for soil. The mixture were digested on a micro Kjeldahl digestion apparatus by setting the temperature $210{ }^{\circ} \mathrm{C}$ and $230^{\circ} \mathrm{C}$ for $2 \mathrm{hr}$ and 2:30 $\mathrm{hr}$ respectively. Then, after the digested solution were allowed to cool for $20 \mathrm{~min}$ without dismantling the condenser from the flask and for $10 \mathrm{~min}$ after removing the condenser. To the cooled solution $25 \mathrm{ml}$ of distilled water was added to dissolve the precipitate formed on cooling and to minimize dissolution of filter paper by the digest residue while filtering with Whatman filter paper. The round bottom flask was rinsed subsequently with $5 \mathrm{ml}$ distilled water until the total volume reached around $45 \mathrm{ml}$. To this final solution, $1 \%$ lanthanum nitrate solution was added and the solution was filled to the mark $(50 \mathrm{ml})$ with distilled water. Triplicate digestions were carried out for each bulk sample. The digested samples were kept in the refrigerator, until the level of all the metals in the sample solutions were determined by FAAS and FAES.

\section{Method Validation and Quality Control Method Validation Precision and Accuracy}

As it can be show in Table-4 the mean percent recovery values ranged between $94.85 \% \mathrm{Fe}$ in soil to $112.8 \%$ ( $\mathrm{Zn}$ in Bulla), all lied in the acceptable range (80-120\%) for metal analysis (USEPA, 2008). This showed that the analytical method provided results in the required level of accuracy. The RSD values of recovery was ranged between $0.05 \%$ ( $\mathrm{Mn}$ in corm and bulla) to $12.2 \%$ ( $\mathrm{K}$ in corm), all lied under the required limit $\leq 15 \%[10]$.

Table-2: Optimization of digestion procedure for $0.5 \mathrm{~g}$ the Soil sample

\begin{tabular}{|c|c|c|c|c|c|c|c|c|}
\hline \multirow[t]{2}{*}{ Trial } & \multirow{2}{*}{$\begin{array}{l}\text { Amounts of } \\
\text { Sample }\end{array}$} & \multicolumn{4}{|c|}{ Volume of Reagents(ml) } & \multirow{2}{*}{$\begin{array}{l}\text { Temperature } \\
\left({ }^{\circ} \mathrm{C}\right)\end{array}$} & \multirow{2}{*}{$\begin{array}{l}\text { Time } \\
\text { (hr) }\end{array}$} & \multirow[t]{2}{*}{ Observation } \\
\hline & & $\mathrm{HNO}_{3}$ & \multicolumn{2}{|c|}{$\mathrm{HClO}_{4}$} & $\mathrm{H}_{2} \mathrm{O}_{2}$ & & & \\
\hline 1 & 0.5 & 4.0 & \multicolumn{2}{|c|}{2.0} & 1.0 & 290 & $3: 00$ & Yellow \\
\hline 2 & 0.5 & 3.5 & \multicolumn{2}{|l|}{2} & 1.5 & 290 & $3: 00$ & Light yellow \\
\hline 3 & 0.5 & 3.0 & \multicolumn{2}{|l|}{1.5} & 1.5 & 290 & $3: 00$ & Very Clear and colorless \\
\hline 4 & 0.5 & 2.5 & \multicolumn{2}{|l|}{2.0} & 1.5 & 290 & $3: 00$ & Light yellow \\
\hline 5 & 0.5 & 2.0 & \multicolumn{2}{|l|}{2.0} & 1.5 & 290 & $3: 00$ & Light yellow \\
\hline 6 & 0.5 & 2.0 & \multicolumn{2}{|l|}{2.0} & 1.0 & 290 & $3: 00$ & Very Clear and colorless \\
\hline 7 & 0.5 & 2.0 & \multicolumn{2}{|l|}{1.5} & 1.0* & 290 & $3: 00$ & Very Clear and colorless \\
\hline 8 & 0.5 & 1.5 & \multicolumn{2}{|l|}{2.0} & 1.0 & 290 & $3: 00$ & Very Clear and colorless \\
\hline \multicolumn{9}{|c|}{ Optimization of Temperature } \\
\hline 1 & 0.5 & 2.0 & 1.5 & \multicolumn{2}{|l|}{1.0} & 190 & $3: 00$ & Yellow \\
\hline 2 & 0.5 & 2.0 & 1.5 & \multicolumn{2}{|l|}{1.0} & 210 & $3: 00$ & Light yellow \\
\hline 3 & 0.5 & 2.0 & 1.5 & \multicolumn{2}{|l|}{1.0} & 230* & $3: 00$ & Very Clear and colorless \\
\hline 4 & 0.5 & 2.0 & 1.5 & \multicolumn{2}{|l|}{1.0} & 250 & $3: 00$ & Very Clear and colorless \\
\hline 5 & 0.5 & 2.0 & 1.5 & \multicolumn{2}{|l|}{1.0} & 270 & $3: 00$ & Very Clear and colorless \\
\hline \multicolumn{9}{|c|}{ Optimization of Time } \\
\hline 1 & \multicolumn{2}{|l|}{0.5} & 2.0 & 1.5 & 1.5 & 230 & $1: 45$ & Yellow \\
\hline 2 & \multicolumn{2}{|l|}{0.5} & 2.0 & 1.5 & 1.5 & 230 & $2: 00$ & Light Yellow \\
\hline 3 & \multicolumn{2}{|l|}{0.5} & 2.0 & 1.5 & 1.5 & 230 & $2: 15$ & Light Yellow \\
\hline 4 & \multicolumn{2}{|l|}{0.5} & 2.0 & 1.5 & 1.5 & 230 & $2: 30 *$ & Very Clear and colorless \\
\hline 5 & \multicolumn{2}{|l|}{0.5} & 2.0 & 1.5 & 1.5 & 230 & $2: 45$ & Very Clear and colorless \\
\hline
\end{tabular}


Teressa Bedada \& Alemayehu Abebaw., Sch Bull, June, 2020; 6(6): 164-173

Table-3: Optimization of digestion procedure for the Bulla of $E$. Ventricosum sample of $0.5 \mathrm{~g}$

\begin{tabular}{|c|c|c|c|c|c|c|}
\hline \multirow[t]{2}{*}{ Trial } & \multirow[t]{2}{*}{ Amounts of Sample } & \multicolumn{2}{|c|}{ Volume of Reagents } & \multirow{2}{*}{$\begin{array}{l}\text { Temperature } \\
\left({ }^{\circ} \mathrm{C}\right)\end{array}$} & \multirow{2}{*}{$\begin{array}{l}\text { Time } \\
\text { (hr) }\end{array}$} & \multirow[t]{2}{*}{ Observation } \\
\hline & & $\mathrm{HNO}_{3}$ & $\mathrm{HClO}_{4}$ & & & \\
\hline 1 & 0.5 & 4.0 & 1.5 & 250 & $2: 45$ & Yellow \\
\hline 2 & 0.5 & 3.5 & 1.5 & 250 & $2: 45$ & Light yellow \\
\hline 3 & 0.5 & 3.5 & 1.0 & 250 & $2: 45$ & Very Clear and colorless \\
\hline 4 & 0.5 & 3.0 & 2.0 & 250 & $2: 45$ & Clear and colorless \\
\hline 5 & 0.5 & 2.5 & 2.0 & 250 & $2: 45$ & Clear and colorless \\
\hline 6 & 0.5 & 2.0 & 2.5 & 250 & $2: 45$ & Very Clear and colorless \\
\hline 7 & 0.5 & 2.0 & $1.5 *$ & 250 & $2: 45$ & Very Clear and colorless \\
\hline \multirow[t]{2}{*}{8} & 0.5 & 1.5 & 1.0 & 250 & $2: 45$ & Light yellow \\
\hline & \multicolumn{6}{|c|}{ Optimization of Temperature } \\
\hline 1 & 0.5 & 2.0 & 1.5 & 150 & $2: 45$ & Light yellow \\
\hline 2 & 0.5 & 2.0 & 1.5 & 170 & $2: 45$ & Clear light yellow \\
\hline 3 & 0.5 & 2.0 & 1.5 & 190 & $2: 45$ & Clear light yellow \\
\hline 4 & 0.5 & 2.0 & 1.5 & $210 *$ & $2: 45$ & Very Clear and colorless \\
\hline \multirow[t]{2}{*}{5} & 0.5 & 2.0 & 1.5 & 230 & $2: 45$ & Very Clear and colorless \\
\hline & \multicolumn{6}{|l|}{ Optimization of Time } \\
\hline 1 & 0.5 & 2.0 & 2.0 & 210 & $1: 30$ & Light yellow \\
\hline 2 & 0.5 & 2.0 & 2.0 & 210 & $1 ; 45$ & Cleary Light yellow \\
\hline 3 & 0.5 & 2.0 & 2.0 & 210 & 2:00* & Very Clear and colorless \\
\hline 4 & 0.5 & 2.0 & 2.0 & 210 & $2: 30$ & Very Clear and colorless \\
\hline
\end{tabular}

Table-4: Recovery and precision test for the optimized procedure from sample spike $(n=3)$

\begin{tabular}{|l|l|l|l|l|l|l|}
\hline Metals & Sample types & $\begin{array}{l}\text { Concentration } \\
\text { in Sample } \\
\left(\mathbf{m g L}^{-1}\right)\end{array}$ & $\begin{array}{l}\text { Amount added } \\
\left(\mathbf{m g L}^{-1}\right)\end{array}$ & $\begin{array}{l}\text { Concentration } \\
\text { in Spike } \\
\left(\mathbf{m g L}^{-1}\right)\end{array}$ & $\begin{array}{l}\text { Recovery } \\
(\%)\end{array}$ & $\begin{array}{l}\text { Precision } \\
(\% \text { RSD })\end{array}$ \\
\hline & Bulla & $14.23 \pm 0.25$ & 1.00 & $15.27 \pm 0.35$ & $104 . \pm 10$ & 9.62 \\
\hline $\mathrm{K}$ & Soil & $34.63 \pm 0.47$ & 1.00 & $35.73 \pm 0.57$ & $110 \pm 11$ & 10.0 \\
\hline & Bulla & $10.01 \pm 0.10$ & 2.00 & $12.10 \pm 0.20$ & $104.50 \pm 5$ & 5.26 \\
\hline $\mathrm{Na}$ & Soil & $10.43 \pm 0.057$ & 2.00 & $12.63 \pm 0.115$ & $110 \pm 2.9$ & 2.64 \\
\hline & Bulla & $0.5830 \pm 0.015$ & 2.00 & $2.52 \pm 0.196$ & $96.85 \pm 2.3$ & 2.30 \\
\hline $\mathrm{Fe}$ & Soil & $1.839 \pm 0.002$ & 2.00 & $3.736 \pm 0.084$ & $94.85 \pm 4.1$ & 4.32 \\
\hline & Bulla & $0.015 \pm 0.006$ & 2.00 & $2.156 \pm 0.007$ & $107.05 \pm 0.05$ & 0.04 \\
\hline $\mathrm{Mn}$ & Soil & $0.999 \pm 0.01$ & 2.00 & $3.029 \pm 0.009$ & $101.50 \pm 0.05$ & 0.05 \\
\hline & Bulla & $0.077 \pm 0.006$ & 1.00 & $1.205 \pm 0.009$ & $112.80 \pm 0.30$ & 0.30 \\
\hline $\mathrm{Zn}$ & Soil & $0.171 \pm 0.027$ & 1.00 & $1.179 \pm 0.072$ & $100.8 \pm 4.50$ & 4.46 \\
\hline & Bulla & $0.078 \pm 0.001$ & 2.00 & $2.196 \pm 0.006$ & $105.90 \pm 0.25$ & 0.24 \\
\hline $\mathrm{Cu}$ & Soil & $0.029 \pm 0.005$ & 2.00 & $2.183 \pm 0.048$ & $107.70 \pm 2.15$ & 1.99 \\
\hline & Bulla & ND & 1.00 & $1.043 \pm 0.001$ & $104.30 \pm 0.10$ & 0.09 \\
\hline $\mathrm{Cd}$ & Soil & $0.004 \pm 0.001$ & 1.00 & $1.009 \pm 0.005$ & $100.50 \pm 0.40$ & 0.04 \\
\hline & Bulla & ND & 1.00 & $1.062 \pm 0.007$ & $106.20 \pm 0.70$ & 0.70 \\
\hline $\mathrm{Pb}$ & Soil & $0.005 \pm 0.0001$ & 1.00 & $1.123 \pm 0.005$ & $112.30 \pm 0.5$ & 0.45 \\
\hline
\end{tabular}

RSD* = Relative standard deviation; ND* Note Detect

\section{Instrument Detection, Method Detection and Quantification Limits}

As it can be observed in Table-5 the method detection values ranged from $0.08 \mathrm{mgkg}^{-1}$ ( $\mathrm{Cd}$ in soil) to $2.441 \mathrm{mgkg}^{-1}(\mathrm{Mn}$ in bulla) and the MDL values lied in range from $0.07 \mathrm{mgkg}^{-1}\left(\mathrm{Cd}\right.$ in Bulla) $6.936 \mathrm{mgkg}^{-1}(\mathrm{Fe}$ in bulla). The results revealed the both MDL and MQL values were greater than the IDL; hence, the results of the analysis could be reliable.

\section{Quality Control \\ Calibration}

Calibration curves for the various concentrations were ranged between 0.9969 and 0.9999 , which were all greater than the required limit $(0.995)$ for trace element analysis (EPA, 2007). This showed that there was good correlation (or relationship) between concentration and absorbance indicating good calibration of instrument. 
Teressa Bedada \& Alemayehu Abebaw., Sch Bull, June, 2020; 6(6): 164-173

Table-5: Instrument detection limit (IDL), method detection limit (MDL), method quantization limit (MQL) and correlation Coefficients of calibration curves for determined in Bulla and soil

\begin{tabular}{|c|c|c|c|c|c|c|c|}
\hline \multirow[t]{2}{*}{ Metals } & \multirow[t]{2}{*}{$\mathbf{R}^{2}$} & \multirow[t]{2}{*}{ calibration equation } & \multirow[t]{2}{*}{ IDL $\left(\mathrm{mgkg}^{-1}\right)$} & \multicolumn{2}{|c|}{ MDL $\left(\mathrm{mgkg}^{-1}\right)$} & \multicolumn{2}{|c|}{ MQL $\left(\mathrm{mgkg}^{-1}\right)$} \\
\hline & & & & Bulla & Soil & Bulla & Soil \\
\hline $\mathrm{K}$ & - & - & 0.004 & 0.512 & 0.478 & 1.73 & 2.23 \\
\hline $\mathrm{Na}$ & & & 0.003 & 0.45 & 0.465 & 1.70 & 1.72 \\
\hline $\mathrm{Fe}$ & 0.9988 & $\bar{Y}=0.0399 x+0.0033$ & 0.003 & 2.441 & 1.187 & 6.94 & 3.76 \\
\hline $\mathrm{Mn}$ & 0.9966 & $Y=0.0019 x+0.0066$ & 0.005 & 2.264 & 1.21 & 7.23 & 3.78 \\
\hline $\mathrm{Zn}$ & 0.9999 & $Y=0.1188 x+0.0033$ & 0.005 & 0.995 & 0.944 & 3.21 & 3.09 \\
\hline $\mathrm{Cu}$ & 0.9999 & $Y=0.788 x+0.0066$ & 0.01 & 1.262 & 1.491 & 3.57 & 4.30 \\
\hline $\mathrm{Cd}$ & 0.9999 & $Y=0.1577 x+0.0033$ & 0.005 & 0.09 & 0.08 & 0.07 & 0.90 \\
\hline $\mathrm{Pb}$ & 0.9988 & $\mathrm{Y}=0.1577+0.0055$ & 0.006 & 0.14 & 0.69 & 0.39 & 0.78 \\
\hline
\end{tabular}

*IDL is Instrument detection limit, MDL is method detection limit and MQL is method quantization limit

\section{Laboratory Control Samples Result}

The percent recovery values of LCS measurements lied in the range $94.0 \%(\mathrm{Na}$ in soil) to $113.6 \%$ ( $\mathrm{Zn}$ in bulla) and their relative standard deviations $0.09(\mathrm{Cu}$ in soil) to 11.37 ( $\mathrm{Cd}$ in soil), and all the values were found under standard control limits 80$120 \%$ for LCS recovery, and $\leq 15 \%$ for $\operatorname{RSD}[10,19]$. This showed that the method used for the study has provided the required level of accuracy and precision throughout the analytical process.

\section{Level of Metals in Bulla of Ensete ventricosum and Soil Samples}

The distribution and variations of The levels of ten metals (four major and six trace) were determined in bulla and soil samples the results were summarized in Table 6 and 7.

\section{Analysis of Metals in Bulla Samples}

The mean concentrations value of major nutrients $(\mathrm{K}, \mathrm{Na}, \mathrm{Mg}$ and $\mathrm{Ca}$ ) in the bulla of Enset sample was studied areas ranged from 3213.33 to $3463.30,1006.67$ to $1336.67,544.22$ to 665.0 and 874.44 to $1041 \mathrm{mg} \mathrm{kg}^{-1}$ respectively. The mean concentrations of $\mathrm{K}$ in the bulla of Enset was highest than all metals analyzed. The lowest $\mathrm{K}, \mathrm{Na}$ and $\mathrm{Mg}$ were observed in Jibat but, $\mathrm{Na}, \mathrm{Mg}$ and $\mathrm{Ca}$ were the highest in Jeldu, which is below the maximum allowed concentration $1-5 \%$ for $\mathrm{K}, 0.1$ to $0.4 \%$ for $\mathrm{Mg}$ and $0.1-$ $1.0 \%$ for $\mathrm{Ca}$ in dry matter of plant FAO [20] and consumption for adults, which is 2 g sodium/day [21].
While, as have compared the concentration of $\mathrm{K}, \mathrm{Na}$, $\mathrm{Mg}$ and $\mathrm{Ca}$ in bulla of this study greater than with the one reported by Minaleshewa and Chandravanshi [8], which was ranged from 708 to 875 for K, 402 to 442 for $\mathrm{Na} 58.4$ to 89.5 for $\mathrm{Mg}$ and 385 to $466 \mathrm{mgkg}^{-1}$ for $\mathrm{Ca}$ respectively. The statistical F-test and ANOVA test showed significant variation $(\mathrm{p}>0.05$, at $95 \% \mathrm{CI}$ ) between the tested bulla and soil samples.

The mean concentrations value of six trace metals ( $\mathrm{Fe}, \mathrm{Mn}, \mathrm{Zn}, \mathrm{Cu}, \mathrm{Cd}$ and $\mathrm{Pb}$ ) in the bulla of Enset sample was studied areas ranged from 50.67 to $58.3,1.57$ to 4.676 .17 to $7.40,3.47$ to $7.84 \mathrm{mg} \mathrm{kg}^{-1}$ respectively. However, $\mathrm{Cd}$ and $\mathrm{Pb}$ could not detect from bulla sample. The concentration of iron was analyzed in the bulla of Enset samples were highest among micro nutrients. The lowest $\mathrm{Fe}$ and $\mathrm{Zn}$ were observed in Jibat but, $\mathrm{Fe}, \mathrm{Zn}$ and $\mathrm{Cu}$ were the highest in Jeldu, which is below the maximum allowed concentration 50-250 mg $\mathrm{kg}^{-1}$ for $\mathrm{Fe}, 20-300$ for $\mathrm{mg} \mathrm{kg}^{-1}$ for $\mathrm{Mn}, 300 \mathrm{mg} \mathrm{kg}^{-1}$ for $\mathrm{Zn}$ and 5-20 mg kg-1 for $\mathrm{Cu}$ in dry matter of plant FAO (2008). While, as have compared the concentration of $\mathrm{Fe}, \mathrm{Mn}, \mathrm{Zn}$ and $\mathrm{Cu}$ in bulla of this study within the range with the one reported by Minaleshewa and Chandravanshi [8], which was ranged from 36.5-59.8 for $\mathrm{Fe}, 1.0-4.98$ for $\mathrm{Mn}, 16.3-22.0$ for $\mathrm{Zn}$ and 2.0$3.5 \mathrm{mgkg}^{-1}$ for $\mathrm{Cu}$ respectively. The statistical F-test and ANOVA test showed significant variation $(\mathrm{p}>0.05$, at $95 \% \mathrm{CI}$ ) between the tested for soil sample except $\mathrm{Fe}$ and $\mathrm{Zn}$ no significant in bulla sample.
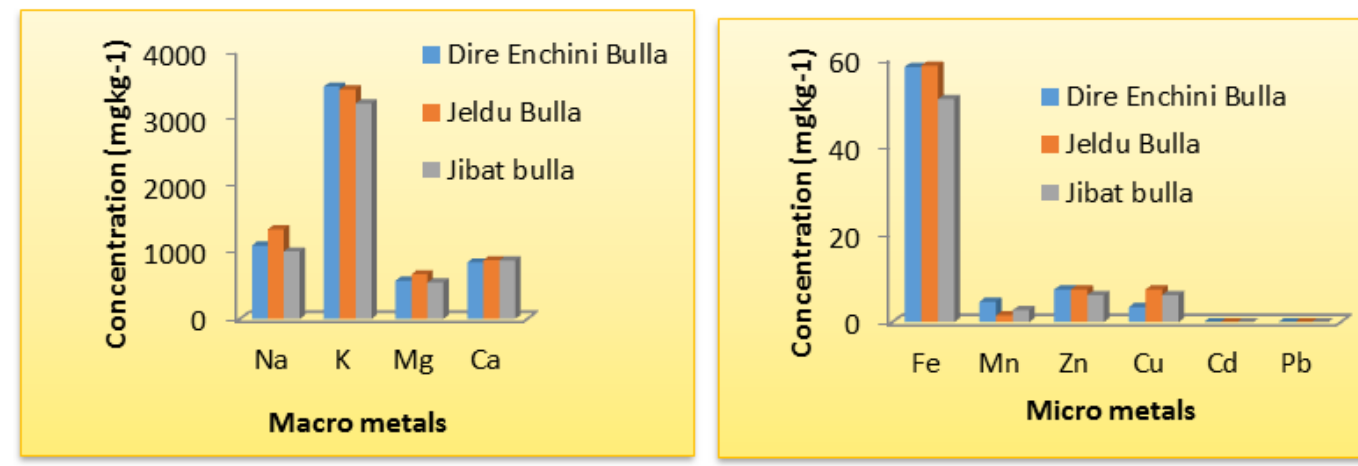

Fig-1: Concentration of metals in Bulla of E. Vectricosum Sample 


\section{Analysis of Metals in Soil Samples}

The mean Concentration of metals in soil As shown in Table-5, the trend of average concentration of metals in soil sampled from Dire Enchini is $\mathrm{K}>\mathrm{Ca}>$ $\mathrm{Na}>\mathrm{Mg}>\mathrm{Fe}>\mathrm{Mn}>\mathrm{Zn}>\mathrm{Cu}$. Similarly, the pattern of the average concentration of metals in soil sampled from Jeldu is $\mathrm{Ca}>\mathrm{K}>\mathrm{Na}>\mathrm{Mg}>\mathrm{Fe}>\mathrm{Mn}>\mathrm{Zn}>\mathrm{Cu}$ and $\mathrm{Ca}>\mathrm{K}>\mathrm{Na}>\mathrm{Mg}>\mathrm{Fe}>\mathrm{Mn}>\mathrm{Zn}>\mathrm{Cu}$ for Jibat district. The statistical F-test and ANOVA test showed significant variation ( $\mathrm{p}>0.05$, at $95 \% \mathrm{CI}$ ) between the tested for soil sample except $\mathrm{Ca}$. The concentrations of all metals in the analyzed soil samples of Enset environment were under the EPA maximum permissible limit of typical concentration in soil dry matter, Fe, Mn, $\mathrm{Cu}, \mathrm{Zn}$ and $\mathrm{Cd}$ are 10-50, 20-30, 2-100, 10-200, 0.1-1 $\mathrm{mg} \mathrm{kg}^{-1}$ respectively [22].

Generally, the results of all the three soil samples showed that $\mathrm{Fe}$ concentration was the highest and $\mathrm{Pb}$ was not detected. when the distribution of the selected essential and non-essential metals over each soil sample of E. Vectricosum was observed, they were found to vary in the order: $\mathrm{K}>\mathrm{Ca}>\mathrm{Mg}>\mathrm{Na}>\mathrm{Fe}>$ $\mathrm{Mn}>\mathrm{Zn}>\mathrm{Cu}>\mathrm{Cd}>\mathrm{Pb}(\mathrm{ND})$ in soil samples of the three areas.
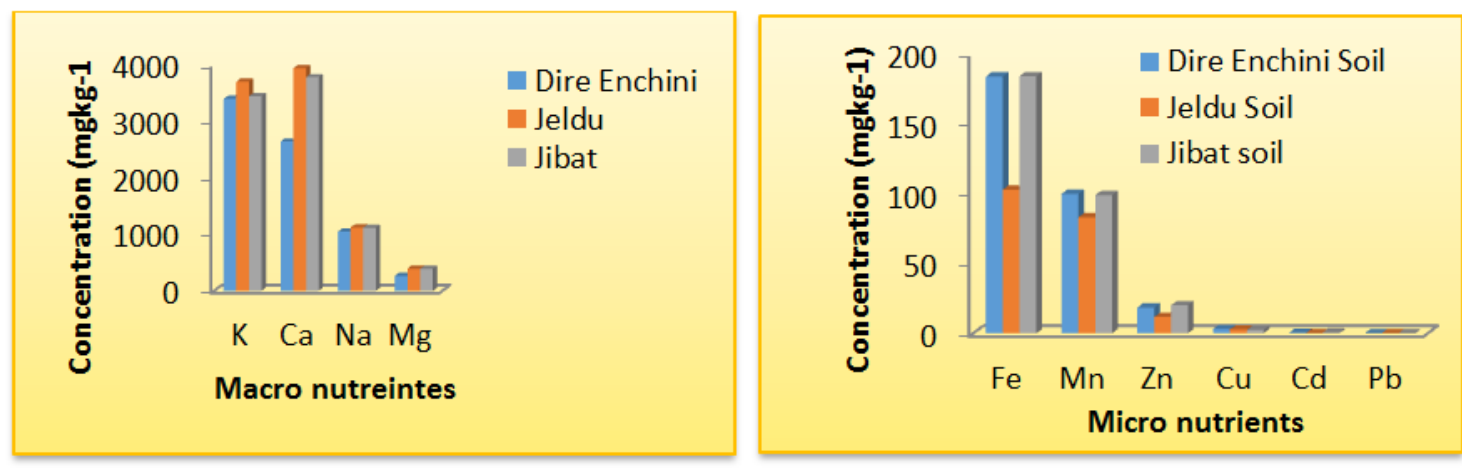

Fig-2: Concentration of metals in Bulla of E. Vectricosum Sample

Table-6: Mean Concentration of Metals (mgkg-1) in Bulla and Soil Samples from Each sites

\begin{tabular}{|c|c|c|c|c|c|c|c|c|}
\hline \multirow[t]{2}{*}{ Metals } & \multicolumn{4}{|l|}{ Bulla } & \multicolumn{4}{|l|}{ Soil } \\
\hline & Dire Echine & Jeldu & Jibat & $\begin{array}{l}\text { Optimum } \\
\text { Range }\end{array}$ & Dire Echine & Jeldu & Jibat & $\begin{array}{l}\text { Optimum } \\
\text { Range }\end{array}$ \\
\hline \multirow[t]{2}{*}{$\mathrm{Na}$} & 1094.70 & 1336.67 & 1006.67 & NA & 1047.33 & 1123.3 & 1120.0 & NA \\
\hline & \pm 5.87 & \pm 647.20 & \pm 40.41 & & \pm 15.53 & \pm 20.83 & \pm 51.96 & \\
\hline \multirow[t]{2}{*}{$\mathrm{K}$} & 3463.30 & 3422.30 & 3213.33 & $1-5 \%^{a}$ & 3403.33 & 3710.0 & 3450.0 & NA \\
\hline & \pm 45.09 & \pm 25.17 & \pm 90.73 & & \pm 5.77 & \pm 78.10 & \pm 170 & \\
\hline \multirow[t]{2}{*}{$\mathrm{Mg}$} & 571.00 & 665.00 & 544.33 & $0.1-0.4 \%^{a}$ & 267.33 & 393.67 & 391.11 & NA \\
\hline & \pm 8.50 & \pm 13.16 & \pm 16.07 & & \pm 10.71 & \pm 5.36 & \pm 28.31 & \\
\hline \multirow[t]{2}{*}{$\mathrm{Ca}$} & 841.67 & 874.44 & 872.44 & $0.1-1 \%^{\mathrm{a}}$ & 2647.33 & 3949.1 & 3788.83 & NA \\
\hline & \pm 14.44 & \pm 5.00 & \pm 8.68 & & \pm 10.08 & \pm 43.74 & \pm 50.08 & \\
\hline \multirow[t]{2}{*}{$\mathrm{Fe}$} & 58.03 & 58.33 & 50.67 & $50-250 \mathrm{mgkg}^{-1 \mathrm{a}}$ & 183.90 & 102.87 & 184.10 & $5000^{a}$ \\
\hline & \pm 0.95 & \pm 0.58 & \pm 4.93 & & \pm 0.17 & \pm 2.11 & \pm 0.85 & \\
\hline \multirow[t]{2}{*}{$\mathrm{Mn}$} & 4.67 & 1.50 & 2.73 & $20-300 \mathrm{mgkg}^{-1 \mathrm{a}}$ & 99.87 & 83.10 & 99.00 & $200^{a}$ \\
\hline & \pm 0.58 & \pm 0.10 & \pm 0.21 & & \pm 0.06 & \pm 1.82 & \pm 2.34 & \\
\hline \multirow[t]{2}{*}{$\mathrm{Zn}$} & 7.40 & 7.40 & 6.17 & $300 \mathrm{mgkg}^{-1 \mathrm{a}}$ & 18.43 & 11.67 & 20.13 & $300^{a}$ \\
\hline & \pm 0.12 & \pm 0.80 & \pm 0.35 & & \pm 0.67 & \pm 0.25 & \pm 1.21 & \\
\hline \multirow[t]{2}{*}{$\mathrm{Cu}$} & 3.47 & 7.84 & 4.00 & $5-20 \mathrm{mgkg}^{-1 \mathrm{a}}$ & 3.07 & 2.73 & 2.50 & $100^{a}$ \\
\hline & \pm 0.50 & \pm 0.05 & \pm 0.01 & & \pm 0.23 & \pm 0.15 & \pm 0.10 & \\
\hline $\mathrm{Cd}$ & ND & ND & ND & $3.0 \mathrm{mgkg}^{-1 \mathrm{~b}}$ & $0.29 \pm 0.1$ & ND & $0.49 \pm 0.01$ & $3.00^{\mathrm{a}}$ \\
\hline $\mathrm{Pb}$ & ND & ND & ND & $100 \mathrm{mgkg}^{-1 b}$ & ND & ND & ND & $100^{a}$ \\
\hline
\end{tabular}

ND is Not Detected, NA is Not Available, ${ }^{a}$ source: (FAO. 2008) [20], ${ }^{b}$ source: FAO/WHO (Codex Alimentation commission (2001) [23].

Table-7: Transfer factor (TF) of Metals from Soil to $E$. Ventricosum

\begin{tabular}{|l|l|l|l|l|l|l|l|l|l|}
\hline \multirow{2}{*}{ Sites } & \multirow{2}{*}{ Sample } & \multicolumn{2}{|l|}{ Metals } \\
\cline { 3 - 10 } & & Na & K & Mg & Ca & Fe & Mn & Zn & Cu \\
\hline Dire Enchini & Bulla & 1.04 & 1.01 & 0.22 & 0.36 & 0.31 & 0.05 & 0.41 & 1.13 \\
\hline Jeldu & Bulla & 1.18 & 0.92 & 0.22 & 0.22 & 0.56 & 0.018 & 0.6 & 2.8 \\
\hline Jibat & Bulla & 0.89 & 0.93 & 0.14 & 0.23 & 0.27 & 0.03 & 0.33 & 1.33 \\
\hline
\end{tabular}


Teressa Bedada \& Alemayehu Abebaw., Sch Bull, June, 2020; 6(6): 164-173

Transfer Factor of Metals from soil to $E$. ventricosum

The transfer factor of metals from soil to plant in this study can be observed $\mathrm{K}, \mathrm{Na}$ and $\mathrm{Cu}$ were more accumulated. When as compared the $\mathrm{TF}$ among the different metals in Bulla $\mathrm{K}, \mathrm{Cu}$ and $\mathrm{Na}$ showed the maximum transfer factor value in Bulla (Table-7), which ranged from $1.01(\mathrm{~K})$ in Dire Enchini ) to $2.8(\mathrm{Cu})$ in Jeldu and $\mathrm{Mn}$ was minimum value which, ranging from 0.02 in Jeldu Bulla to 0.05 in Dire Enchini Bulla. This is indicated that Bulla is rich in essential metals.

Table-8: Comparison of the metals concentration of unprocessed Bulla of E.ventricosum and Soil samples were determined in this study and other literature

\begin{tabular}{|l|l|l|l|l|}
\hline Metals & $\begin{array}{l}\text { Uncrossed Bulla of } \\
\text { E.ventricosum } \\
\text { this study }\end{array}$ & $\begin{array}{l}\text { Processed food product Bulla } \\
\text { of E.ventricosum (Minaleshewa } \\
\text { and Chandravanchi, 2008) [8] }\end{array}$ & $\begin{array}{l}\text { Metals } \\
\text { concentration of soil } \\
\text { in this study }\end{array}$ & $\begin{array}{l}\text { Metals concentration } \\
\text { of soil (Menegesha } \text { et } \\
\text { al., 2014) [24] }\end{array}$ \\
\hline $\mathrm{Na}$ & $1006.7-1336.7$ & $402-464$ & $1073-1123$ & $\mathrm{NR}$ \\
\hline $\mathrm{K}$ & $3213.3-3463.3$ & $708-875$ & $3403-3710$ & $2300.17-2382$ \\
\hline $\mathrm{Ca}$ & $841.3-874.4$ & $385-446$ & $2966.67-9633.33$ & $55.2-56.52$ \\
\hline $\mathrm{Mg}$ & $544-665$ & $58.4-89.5$ & $469.67-543.30$ & $914.83-939.17$ \\
\hline $\mathrm{Fe}$ & $50.67-58.33$ & $36.6-59.8$ & $102.87-184.10$ & $\mathrm{NR}$ \\
\hline $\mathrm{Mn}$ & $1.57-4.67$ & $\mathrm{ND}-5.38$ & $83.10-99.87$ & $942-953.5$ \\
\hline $\mathrm{Zn}$ & $6.17-7.40$ & $2.01-3.53$ & $11.67-20.13$ & $55-60.97$ \\
\hline $\mathrm{Cu}$ & $3.47-7.84$ & $2.01-3.53$ & $2.50-3.03$ & $35.46-39.67$ \\
\hline $\mathrm{Cd}$ & $\mathrm{ND}$ & $\mathrm{ND}-5.61$ & $\mathrm{NR}$ & $\mathrm{NR}$ \\
\hline $\mathrm{Pb}$ & $\mathrm{ND}$ & $\mathrm{ND}$ & $\mathrm{ND}$ & $12.97-15$ \\
\hline
\end{tabular}

\section{Correlation Analysis}

The relationships between the essential and non essential metals were analyzed by Pearson's correlation coefficient the high correlation coefficient near +1 or -1 is a good relation between two variables and around zero no relation between them. If $\mathrm{r}> \pm 0.7$ strongly correlation and $r$ value between \pm 0.5 to \pm 0.7 moderated correlation between two different parameters [25].
As show in Table-5 strong positive correlation were observed for metals in soil between $\mathrm{Na}$ with $\mathrm{Mg}$ and $\mathrm{Ca}, \mathrm{K}$ with $\mathrm{Ca}$ and $\mathrm{Fe}, \mathrm{Mg}$ with $\mathrm{Ca}, \mathrm{Fe}$ with $\mathrm{Mg}$ and $\mathrm{Zn}, \mathrm{Mn}$ with $\mathrm{Zn}$ and $\mathrm{Cd}, \mathrm{Zn}$ with $\mathrm{Cd}$. Moderate positive correlations were observed between $\mathrm{Na}$ with $\mathrm{K}$, K with $\mathrm{Mg}$. Whereas a strong negative correlation were found between $\mathrm{Na}$ with $\mathrm{Cu}, \mathrm{K}$ with $\mathrm{Mn}, \mathrm{Zn}$ and $\mathrm{Cd}, \mathrm{Mg}$ with $\mathrm{Cu}$. There was also moderately negative correlation between $\mathrm{Na}$ with $\mathrm{Fe}$ and $\mathrm{Mn}, \mathrm{Ca}$ with $\mathrm{Fe}$ and $\mathrm{Mn}$ ). The other correlations were weak.

Table-10: Pearson's correlation coefficients between Bulla samples in three districts

\begin{tabular}{|c|c|c|c|c|c|c|c|c|}
\hline & $\mathrm{Na}$ & $\mathbf{K}$ & Mg & $\mathrm{Ca}$ & $\mathrm{Fe}$ & Mn & $\mathbf{Z n}$ & $\mathrm{Cd}$ \\
\hline $\mathrm{Na}$ & 1 & & & & & & & \\
\hline $\mathrm{K}$ & 0.59 & 1 & & & & & & \\
\hline $\mathrm{Mg}$ & 0.999* & 0.55 & 1 & & & & & \\
\hline $\mathrm{Ca}$ & 0.312 & -0.583 & 0.358 & 1 & & & & \\
\hline $\mathrm{Fe}$ & 0.73 & 0.982 & 0.696 & -0.421 & 1 & & & \\
\hline $\mathrm{Mn}$ & -0.599 & 0.293 & -0.637 & -0.948 & 0.109 & 1 & & \\
\hline $\mathrm{Zn}$ & 0.706 & 0.988 & 0.671 & -0.452 & 0.999 & 0.144 & 1 & \\
\hline $\mathrm{Cu}$ & 0.932 & 0.256 & 0.948 & 0.632 & 0.432 & -0.849 & 0.401 & 1 \\
\hline \multicolumn{9}{|c|}{ Table 10: Pearson's correlation coefficients between soil samples in three districts } \\
\hline & $\mathrm{Na}$ & $\mathrm{K}$ & $\mathrm{Mg}$ & $\mathrm{Ca}$ & $\mathrm{Fe}$ & $\mathrm{Mn}$ & $\mathrm{Zn}$ & $\mathrm{Cd}$ \\
\hline $\mathrm{Na}$ & 1 & & & & & & & \\
\hline $\mathrm{K}$ & 0.647 & 1 & & & & & & \\
\hline $\mathrm{Mg}$ & $1.00 * *$ & 0.63 & 1 & & & & & \\
\hline $\mathrm{Ca}$ & $0.997 *$ & 0.702 & $0.995^{*}$ & 1 & & & & \\
\hline $\mathrm{Fe}$ & -0.531 & 0.999* & -0.512 & -0.591 & 1 & & & \\
\hline $\mathrm{Mn}$ & -0.572 & $0.995^{*}$ & -0.553 & -0.631 & $0.999 *$ & 1 & & \\
\hline $\mathrm{Zn}$ & 0.363 & -0.945 & -0.341 & -0.431 & 0.982 & 0.972 & 1 & \\
\hline $\mathrm{Cu}$ & 0.932 & -0.25 & -0.91 & -0.861 & 0.109 & 0.156 & -0.08 & 1 \\
\hline $\mathrm{Cd}$ & -0.149 & -0.847 & -0.127 & -0.271 & 0.915 & 0.894 & 0.974 & 1 \\
\hline
\end{tabular}

$*$ Correlation is significant at the level of 0.05 levels (1-tailled) ** Correlation is significant at the level of 0.01 levels (1tailled). 


\section{CONCLUSION}

The optimized wet digestion method for Bulla and soil analysis was found effective for all of the minerals and as it was evaluated through the recovery experiment, a good percentage recovery $96 \%$ (Fe in Bulla) to $112.3 \%$ ( $\mathrm{Pb}$ in soil) was obtained for the minerals identified. In this study the levels of ten elements in the three different district in West Showa zone. The metal contents of soil sample were found to be highest than Bulla in all analyzed except $\mathrm{Zn}, \mathrm{Cu}$ and $\mathrm{Na}$. The metals such as $\mathrm{K}, \mathrm{Ca}, \mathrm{Mg}$ and $\mathrm{Na}$ were generally found in highest concentrations than the rest metal in all of the samples.

Generally, this study showed that high level of macro elements ( $\mathrm{K}, \mathrm{Mg}, \mathrm{Ca}$ and $\mathrm{Na}$ ) were accumulated in Bulla samples collected from the studied areas and high level of $\mathrm{Fe}$ from the micro nutrient followed copper. When, the distribution of the selected essential and non-essential metals over Bulla sample of $E$. Vectricosum was observed, they were found to vary in the order of decreasing $\mathrm{K}>\mathrm{Na}>\mathrm{Ca}>\mathrm{Mg}>\mathrm{Fe}>\mathrm{Zn}>$ $\mathrm{Cu}>\mathrm{Mn}$ in Bulla samples of the three areas. However, $\mathrm{Cd}$ and $\mathrm{Pb}$ could not be detected in Bulla. Based on the WHO recommended limit and FAO [20] the maximum permissible limit for plant, $\mathrm{K}, \mathrm{Na}, \mathrm{Mg}, \mathrm{Ca}, \mathrm{Fe}, \mathrm{Mn}, \mathrm{Cu}$, $\mathrm{Zn}$ and $\mathrm{Pb}, \mathrm{Cd}$ were not found to cause any risk to the people by consuming the E. Vectricosum plants grown in the area where the E. Vectricosum is planted( studied areas). The results of all the three soil samples showed that $\mathrm{K}$ concentration was the highest and $\mathrm{Pb}$ was not detected. When, the distribution of the selected essential and non-essential metals over each soil sample of $E$. Vectricosum was observed, they were found to vary in the order: $\mathrm{K}>\mathrm{Ca}>\mathrm{Mg}>\mathrm{Na}>\mathrm{Fe}>\mathrm{Mn}>\mathrm{Zn}>\mathrm{Cu}>$ $\mathrm{Cd}>\mathrm{Pb}(\mathrm{ND})$ in soil samples of the three areas.

\section{ACKNOWLEDGEMENT}

The authors would like thank to the Nono Woreda Education office for sponsoring his study and the Department of Chemistry, Ambo University, Ethiopia, for providing the laboratory facilities and the necessary supports.

\section{REFERENCES}

1. Spring, A., Haile, B., Tesfaye, S., Abebe, Y., Amaldegen, A., Gizachew, W., ... \& Habte, T. (1996). Enset farming systems in southern region, Ethiopia: Report on a rapid rural appraisal in Gurage, Hadiya, and Sidama zones. Addis Ababa: GTZ.

2. Spring, A., Diro, M., A Brandt, S., Tabogie, E., Wolde-Michael, G., McCabe, J. T., ... \& Yntiso, G. (1997). Tree Against Hunger: Enset-based Agricultural Systems in Ethiopia. American Association for the Advancement of science, Washington, DC. 1-41.

3. Birmeta, G., Nybom, H., \& Bekele, E. (2004). Distinction between wild and cultivated enset
(Ensete ventricosum) gene pools in Ethiopia using RAPD markers. Hereditas, 140(2), 139-148.

4. Shank, R., \& Chernet, E. (1996). Enset crop assessment, United Nations World Food Programme, Bureau Agriculture, SNNPRS, UNDP Emergencies Unit for Ethiopia.

5. Kamar, S., Baah, F. A., Pozo, E., Taye Kufa, A. Z., \& Okwadi, J. (2000). Research and development options for enhancing income and sustainability of farming systems in Kafa-Sheka zone of Ethiopia. International Centre for Development Oriented Research in Agriculture, Wageningen, The Netherlands.

6. Negash, A., Tsegaye, A., van Treuren, R., \& Visser, B. (2002). AFLP analysis of enset clonal diversity in south and southwestern Ethiopia for conservation. Crop Science, 42(4), 1105-1111.

7. Mohammed, B., Gabel, M., \& Karlsson, L. M. (2013). Nutritive values of the drought tolerant food and fodder crop enset. African Journal of Agricultural Research, 8(20), 2326-2333.

8. Atlabachew, M., \& Chandravanshi, B. S. (2008). Levels of major, minor and trace elements in commercially available enset (Ensete ventricosum (Welw.), Cheesman) food products (Kocho and Bulla) in Ethiopia. Journal of Food Composition and Analysis, 21(7), 545-552.

9. Endashaw, B. (2007). Study on actual situation of medicinal plants in Ethiopia. Japan Association for International Collaboration of Agriculture and Forestry, 2, 1-9.

10. Csuros, M., \& Csuros, C. (2002). Environmental sampling and analysis for metals Lewis publishers, A CRC Press Company Boca Raton London, New York, Washington, D.C.

11. Mitra, S. (2003). Sample preparation techniques in analytical chemistry, John Wiley and Sons Hoboken, New Jersey, 162:6-244.

12. Iqbal, J., Carney, W. A., LaCaze, S., \& Theegala, C. S. (2010). Metals determination in biodiesel (B100) by ICP-OES with microwave assisted acid digestion. The Open Analytical Chemistry Journal, 4(1):18-26.

13. USEPA. (2008). National functional guidelines for superfund organic methods data Review USEPA540-R08-01, Washington, DC

14. Miller, N., \& Miller, J. (2010). Statistics and chemo metrics for analytical chemistry $6^{\text {th }}$ edition, Pearson Education limited, UK.

15. Addis, W., \& Abebaw, A. (2015). Analysis of selected physicochemical parameters of soils used for cultivation of garlic (Allium sativum L.). Science, Technology and Arts Research Journal, 3(4), 29-35.

16. Marella, A. (2010). Laboratory quality assurance and quality control guidance reasonable Confidence Protocols, 79 Elm Street, Hartford.

17. Harrison, R., \& Chirgawi, M. (1989). The assessment of air and soil as contribution of trace 
metals to vegetable plants Use of the filtered air growth cabinet. Sci total enviro, 83:13-34.

18. Uwah, E. I., Gimba, M. S., \& Gwaski, P. A. (2012). Determination of $\mathrm{Zn}, \mathrm{Mn}, \mathrm{Fe}$ and $\mathrm{Cu}$ in spinach and lettuce cultivated in Potiskum, Yobe State, Nigeria. Journal of agricultural Economics and Development, 1(4), 69-74.

19. Mulu, A., Kassu, A., Anagaw, B., Moges, B., Gelaw, A., Alemayehu, M., ... \& Isogai, E. (2013). Frequent detection of 'azole'resistant Candida species among late presenting AIDS patients in northwest Ethiopia. BMC infectious diseases, 13(1), 82.

20. FAO. (2008). Guide to Laboratory Establishment for Plant Nutrient Analysis by Roy RN., M.R. Motsara, Rome. FOA fertilizer and plant nutrition bulletin, 19:1-219.

21. WHO. (2008). Permissible limits of heavy metals in soil and plants, (Genava: World Health Organization), Switzerland.
22. Epa, U. (2002). Method 1631, Revision E: Mercury in water by oxidation, purge and trap, and cold vapor atomic fluorescence spectrometry. US Environmental Protection Agency Washington, $D C$.

23. FAO/WHO (Codex, Alimentarium commission). (2001). Food additive and contaminants Join FAO/WHO standard programme ALINORM 01/12A, 1-289.

24. Tigist, M., Rao, V. M., \& Faye, G. (2014). Determination of essential and non-essential metals concentration in papaya (Carica papaya) seeds, leaves and supporting soil of Odo-Shakiso district in South East Oromia Region, Ethiopia. Int J Res Pharm Chem [Internet], 4(1), 202-16.

25. Sharma, M. R., \& Raju, N. S. (2013). Correlation of heavy metal contamination with soil properties of industrial areas of Mysore, Karnataka, India by cluster analysis. International Research Journal of Environment Sciences, 2(10), 22-27. 